\title{
A16974C polymorphism of the IL-12 p40 gene in Cuban patients having recovered from COVID-19
}

Estela Morales Peralta ${ }^{*}$, Yaíma Zúñiga Rosales², Teresa Collazo Mesa², Elvia Nelemi Santos González² , Yadira Hernández Pérez², María de los Angeles González Torres², Hilda Roblejo Balbuena², Beatriz Marcheco Teruel ${ }^{2}$ DOI. 10.21931/RB/2022.07.01.34

110 de Octubre University Hospital. Havana, Cuba.

${ }^{2}$ National Medical Genetics Center. Havana, Cuba.

Corresponding author: fornaris@infomed.sld.cu

Abstract: COVID-19 has had severe consequences worldwide. It has been estimated that the contribution of genetic factors to the disease is about 50\%. The A16974C polymorphism of the IL-12 p40 gene has been described as being related to resistance or susceptibility to other infectious diseases; therefore, it is likely that it can also be related to COVID-19. The objective of this study was to describe the relationship between the A16974C polymorphism of the IL12 p40 gene with clinical forms of COVID-19 in Cuban patients. The genotypes of the A16974C polymorphism of gene IL-12 p40 were determined through PCR in 102 persons with a COVID-19 epidemiologic discharge from the hospital. In this research, the CC genotype of this polymorphism was found only in symptomatic cases of this disease; since there are signs of relationship between the A16974C polymorphism of the IL12 p40 gene with clinical forms of COVID-19 in the studied Cuban patients, the variations of this polymorphism may be a predisposing risk factor in the development of COVID-19.

Key words: COVID-19, genetic polymorphism, genetic predisposition to disease, genetic susceptibility, human genetic variants, Cuba, alleles.

\section{Introduction}

Infectious diseases are produced by the interaction between the agent's characteristics, the environment and the host. Human variations or polymorphisms have been identified among the latter, which are related to the clinical course of the disease. This occurs with the c.554_585del mutation of the CCR5 gene, linked to the resistance to the progression of the acquired immunodeficiency syndrome and the c.1521 1523delCTT of gene CFTR -the cause of cystic fibrosis- that confers susceptibility to infection by Pseudomonas aeruginosa, to give two examples ${ }^{1}$.

COVID-19 (the acronym of COronaVIrus Disease and the year 2019), produced by the SARS-CoV-2 virus (from severe acute respiratory syndrome coronavirus 2), has had severe consequences worldwide?

Studies in twins demonstrated that the concordance of the clinical severity of COVID-19 is greater among monozygotic twins, estimating that the contribution of genetic factors to this disease is approximately $50 \%^{3}$. Therefore, there is evidence that the genetic constitution, with its variations, contributes to the predisposition or resistance to this disease ${ }^{4}$.

In relation to the pathophysiology of COVID-19, a group of genes may possibly participate in the risk of contracting the disease or its more severe forms. These include genes coding for the virus receptors, those related to inflammation and immune response, as well as those involved in clotting and the acute res- piratory distress syndrome. Those related to inflammation and immune response comprise genes coding for pro-inflammatory cytokines, including interleukins 1, 6, 12 (IL-1, IL-6, IL-12) $)^{1,4}$.

Interleukin 12 (IL-12) promotes cell immunity. It plays an essential role in the differentiation of lymphocytes $T$ towards the T helper 1 (Th1) pattern and the increase in the cytotoxic activity of the Natural Killer (NK) cells against viral infections and other intracellular pathogens ${ }^{5}$. It also participates in the induction of an increase in the synthesis and secretion of other cytokines, such as IL-1, IL-6, IFN- $\gamma$, and TNF-a, producing the "cytokine storm"6, which is a sign of a poor prognosis of COVID-19 (Figure 1$)^{7}$. Therefore, variants of the genes coding for the synthesis of the IL-12, such as A16974C polymorphism, may also be related to an increase in the susceptibility to SARS-CoV-28,9.

By identifying the genetic variants of the Cuban population that have a predisposition to developing COVID-19, and even in its most severe clinical forms, we can design prevention strategies that range from vaccination to therapeutic measures. This may help generate a clinical guide for the management and advances in genomic medicine applied to COVID-19 management.

The objective of this study was to describe the relationship between the A16974C polymorphism of the IL12 p40 gene with clinical forms of COVID-19 in Cuban patients.

Citation: Morales Peralta E, Zúñiga Rosales Y, Collazo Mesa T, Santos González E, Hernández Pérez Y, González Torres M, Roblejo Balbuena H, Marcheco Teruel B. A16974C polymorphism of the IL-12 p40 gene in Cuban patients having recovered from COVID-19. Revis Bionatura 2022;7(1). 34. http://dx.doi.org/10.21931/RB/2022.07.01.34

Received: 20 October 2021 / Accepted: 13 December 2021 / Published: 15 February 2022

Publisher's Note: Bionatura stays neutral with regard to jurisdictional claims in published maps and institutional affiliations. 


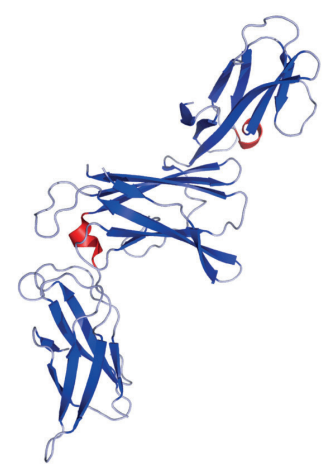

IL-12

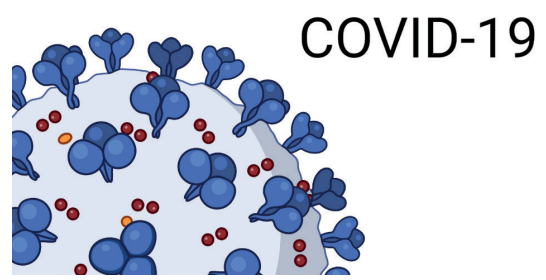

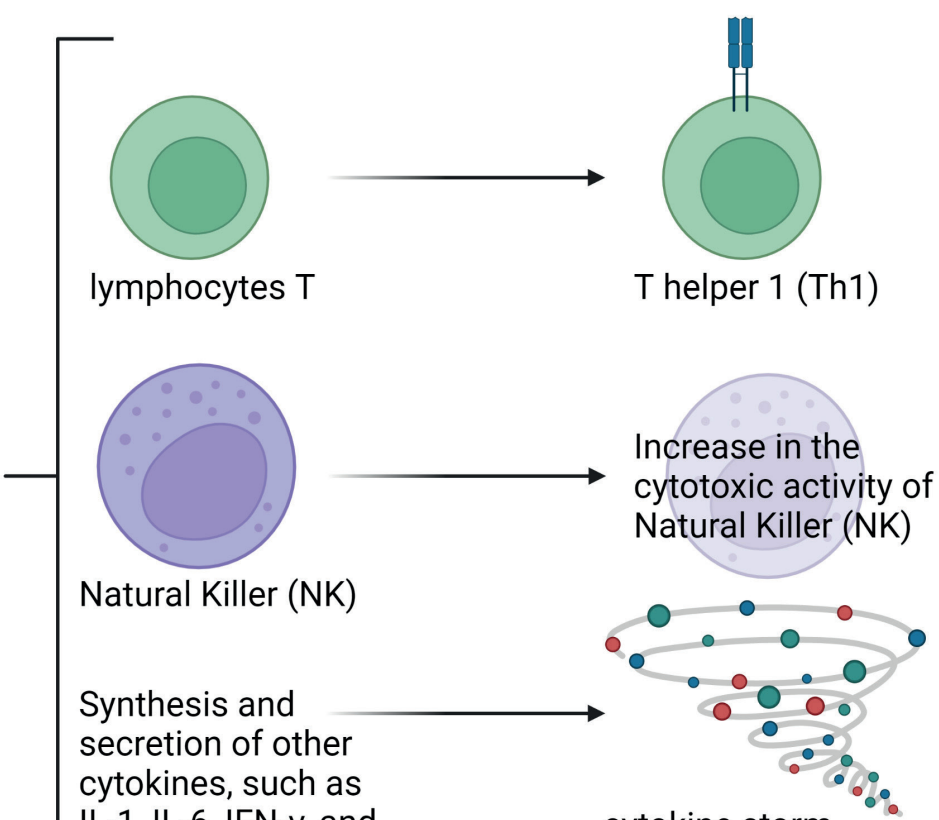

cytokine storm TNF-a

Figure 1. The immunopathological mechanisms of COVID-CS. SARS-CoV-2 infects the epithelial cells or immune cells, causing tissue damage and release of inflammatory cytokines (e.g., IL-1, IL-6, IL-12, and TNFa) by epithelial cells and immune cells. These inflammatory cytokines then recruit innate immune cells (monocytes, macrophages, neutrophils, DCs, and NK cells) and activate adaptive immune cells (CD4 ${ }^{+} \mathrm{T}$ cells and $\mathrm{CD} 8^{+} \mathrm{T}$ cells) to induce the occurrence of myelopoiesis and emergency granulopoiesis, as well as the production of sustained and excessive circulating cytokines.

\section{Materials and methods}

\section{Subjects /patients}

A sample of 102 patients was randomly taken from all Cuban patients over one year of age, who initially tested positive for Sars-CoV-2 by RT-PCR (Reverse transcription-polymerase chain reaction) and tested negative twice as of June 11, 2020, for SARS-CoV-2 by RT-PCR, in 14 days after being discharged from the hospital.

\section{Demographic variables}

EDemographic variables included age in years, skin color (according to the patient's self-perception) and sex. These were taken from a survey designed for the project: "Genetic risk factors associated to the clinical severity of COVID-19 in Cuban patients and their first-degree relatives", in which this study was included.

The persons studied were classified according to the clinical forms of the disease (considering whether they had symptoms or not) as symptomatic and asymptomatic, respectively.

\section{Molecular studies}

The DNA was obtained from $4 \mathrm{~mL}$ of peripheral blood collected in a Vacutainer with EDTA (K3E 7.2mg). QIAsymphony DNA kits were used following the manufacturer's instructions ${ }^{10}$.

To identify the alleles of the A16974C polymorphism, we used the polymerase chain reaction (PCR) described by See- gers et al. We designated alleles $\mathrm{A}$ and $\mathrm{C}$ from this polymorphism, as defined by the above authors ${ }^{9}$.

\section{The sequences of the primers used were}

\section{Forward: 5'-ATT-TGG-AGG-AAA-AGT-GGA-AGA-3'}

Reverse: 5'-AAT-TTC-ATG-TCC-TTA-GCC-ATA-3'

The amplifications were made in an MJ Research thermocycler in the following way: primary denaturalization (10 min at $94^{\circ} \mathrm{C}$ ), followed by 30 cycles of: denaturalization (30 s at 94 $\left.{ }^{\circ} \mathrm{C}\right)$, hybridization ( $30 \mathrm{~s}$ at $65^{\circ} \mathrm{C}$ ) and elongation:

30 s at $72{ }^{\circ} \mathrm{C}$, with the final extension at $72^{\circ} \mathrm{C}$ for 10 minutes.

To verify each amplification, we carried out an electrophoretic run in $2 \%$ agarose gel stained with ethidium bromide, with a molecular weight marker of $100 \mathrm{bp}$, at a fixed voltage of 250 $\checkmark$. The amplification was verified when we identified that the fragment obtained was 1046 base pairs (bp).

The amplified product was digested with the Taq I restriction enzyme because of its recognition sequence and enzymatic digestions:

\section{$5^{\prime} \quad \mathrm{T} \quad \downarrow \quad \mathrm{C} \quad \mathrm{G} \quad \mathrm{A}$ \\ $\begin{array}{llllll} & A & G & \uparrow & C & T\end{array}$}

This procedure was made under the manufacturer's conditions, which recommends the use of $10 \mu \mathrm{l}$ of the product of the PCR, $2 \mu \mathrm{l}$ (20U) of the Taq I enzyme, $3.5 \mu \mathrm{l}$ of buffer B, and $19.5 \mu \mathrm{l}$ of $\mathrm{H} 2 \mathrm{O}$. The incubation was performed at $65^{\circ} \mathrm{C}$ overnight. 
The processed product was then submitted to a run in $2 \%$ agarose gel for 30 minutes at $250 \mathrm{~V}$, with a molecular weight marker of $100 \mathrm{bp}$. The genotypes related to the polymorphisms that were obtained were: an entire fragment of $1046 \mathrm{bp}$, corresponding to the homozygous genotype for allele $A$; for the homozygous genotype of allele $\mathrm{C}$, we obtained two fragments, one of $906 \mathrm{bp}$ and the other of $140 \mathrm{bp}$, and the three fragments (1046, 906 and 140 bp) for the heterozygote.

\section{Processing, analysis, summary and presentation of the information:}

The data obtained were processed with the IBM SPSS Statistics software version 22.0. The absolute and relative frequencies were calculated (percentage).

\section{Bioethical issues}

This research was part of the project named "Genetic risk factors associated to the clinical severity of COVID-19 in Cuban patients and their first-degree relatives", approved by the Research Ethics Committee of the National Medical Genetics Center. Throughout its implementation, we supervised the compliance to the ethical principles for human medical research, including in the Helsinki Declaration ${ }^{11}$. All participants in this research signed written consent for their participation, and in the case of children under 16 years of age, they were represented by their parents or tutors.

\section{Results}

Demographic characteristics of the patients infected with SARS-CoV-2 are shown in table 1; they included age, sex and skin color, according to the clinical forms of the malady considered in this investigation (asymptomatic or symptomatic).

The average age of the patients was 52 years old $(95 \% \mathrm{Cl}$ 48-55), ranging from 4 to 96 years of age. The mean age was more significant in symptomatic patients than asymptomatic patients (55 compared to 39), increasing the proportion of symptomatic patients with age. More females were included in the study, and they were predominant in both clinical forms. The number of individuals with white skin color was more remarkable in both clinical categories.

Table 2 shows the number of patients studied according to their genotype for the A16974C polymorphism of the IL12p40 gene and their clinical forms. Genotype CC was not present in those showing asymptomatic forms.

The alleles $A$ and $C$ frequency were $0.75 \%$ and $0.25 \%$ $0.83 \%$ and $0.17 \%$ for symptomatic and asymptomatic patients, respectively.

\section{Discussion}

The SARS-CoV-2 infection and the development of clinical forms of COVID-19 could be influenced by several factors, of which the immunological genotype-phenotype relationship is of particular interest. It is essential to identify the persons with the highest risks for applying preventive measures so that their care can be personalized as much as possible.

It was found that the average age was higher in symptomatic cases. Similar results were described in the literature ${ }^{12}$. The factors explaining this finding include the alteration of the innate and adaptive immune response with a decreased capacity for responding specifically to new antigens (immuno-

\begin{tabular}{|c|c|c|}
\hline \multirow[t]{2}{*}{ Characteristics } & \multicolumn{2}{|c|}{$\begin{array}{l}\text { Groups according to the clinical form of } \\
\text { the disease. No. (\%) }\end{array}$} \\
\hline & $\begin{array}{l}\text { Asymptomatic } \\
(\mathrm{n}=20)\end{array}$ & Symptomatic $(n=82)$ \\
\hline \multicolumn{3}{|l|}{ Age (years) } \\
\hline$<20$ & $4(20 \%)$ & $3(3.7 \%)$ \\
\hline $20-39$ & $7(35 \%)$ & $13(15.8 \%)$ \\
\hline $40-59$ & $6(30 \%)$ & $36(44 \%)$ \\
\hline$\geq 60$ & $3(15 \%)$ & $30(36.5 \%)$ \\
\hline Median (IQR) & $38(25-51)$ & $55(43-67)$ \\
\hline $\begin{array}{l}\text { Mean }(95 \% \mathrm{Cl} \\
\text { minimum;maximum })\end{array}$ & $39(31 ; 47)$ & $55(51 ; 59)$ \\
\hline \multicolumn{3}{|l|}{ Sex } \\
\hline Male & $8(40.0 \%)$ & $35(42.7 \%)$ \\
\hline Female & $12(60.0 \%)$ & $47(57.3 \%)$ \\
\hline \multicolumn{3}{|l|}{ Skin color* } \\
\hline White & $12(60.0 \%)$ & $54(66.7)$ \\
\hline Mestizo & $5(25.0 \%)$ & $22(27.1 \%)$ \\
\hline Black & $3(15.0 \%)$ & $5(6.2 \%)$ \\
\hline
\end{tabular}

Table 1. Distribution of the patients infected with SARS-CoV-2 in the study, according to age, sex, and skin color, depends on the disease's clinical forms. 


\begin{tabular}{|c|c|c|c|}
\hline \multirow[b]{2}{*}{ CHARACTERISTICS } & \multicolumn{3}{|c|}{ GENOTYPES } \\
\hline & AA & AC & CC \\
\hline \multicolumn{4}{|c|}{ Clinical forms } \\
\hline Symptomatic $(n=82)$ & $43(52.43 \%)$ & $37(45.12 \%)$ & $2(2.43 \%)$ \\
\hline Asymptomatic $(n=20)$ & $13(65 \%)$ & $7 \quad(35 \%)$ & 0 \\
\hline
\end{tabular}

Table 2. Clinical forms in patients infected by SARS-CoV-2 according to the polymorphic genotypes of A16974C of the IL12p40 gene.

senescence), the trend towards mainly pro-inflammatory response (low degree inflammation or "inflamm-aging") ${ }^{13}$, and the increase of the probability of having comorbidities ${ }^{14,15}$.

This study's comparatively higher incidence of affected women may be because it was carried out through home visits to recovered patients who had resumed their usual occupations. For this reason, the voluntary collaboration of women was more significant. The highest proportion of the recruited individuals was of white skin, agreeing with the results of other studies made in the same population ${ }^{16}$. The proportion observed for this skin color agrees with the Cuban population census of the year $2012^{17}$.

COVID-19 is related to a series of pathophysiological mechanisms mobilizing many biomolecules. In the more severe cases, the prognoses may be markedly worsened by the hyperproduction of cytokines (frequently called the cytokine storm), leading to vascular damage, the activation of other immune response mechanisms and the worsening of clinical results ${ }^{18}$. The cytokines include $\mathrm{IL}-12^{9}$, coding for a gene located at $5 q 33.3$ of which several polymorphisms have been described ${ }^{19}$. The one explored here was identified through the Taq I enzyme, and it is found at the untranslatable 3 ' region of the gene, at position 16974, which enables the identification of alleles $A$ and $C$, given by the presence of adenine or cytosine, and corresponding to the absence or presence of the cut at the Taq I enzyme. It is considered that allele $A$ is the wild type and that $\mathrm{C}$ affects the secretion of IL-12 in vitro ${ }^{9}$. Genotype $\mathrm{CC}$, and of course, allele $\mathrm{C}$, had the lowest frequency in all populations, including the normal Cuban population ${ }^{20}$, and it has been associated with the predisposition to several diseases ${ }^{21}$. In fact, this genotype was not found in the asymptomatic cases included in this study. These results could prove that the clinical form may be related to the genotypes studied. The variants evaluated here can be used for prognosis purposes, including those related to a higher probability of presenting complications or more severe clinical conditions. This can be important in the personalized care of the patients, and above all, in terms of disease prevention.

All results observed can be explained by the small sample size of this study, which was a significant limitation of this research; the results of this type of research are applicable to the population where it was carried out.

Studies, such as the one shown here will help identify the genetic variants or polymorphisms related to diseases that do not show Mendelian inheritance, including infectious diseases $^{22}$. More in-depth studies on this topic are required in the future.

\section{Conclusions}

Since there are signs of relationship between the A16974C polymorphism of the IL12 p40 gene with clinical forms of COVID-19 in the studied Cuban patients, the variations of this polymorphism may be a predisposing risk factor in the development of COVID-19.

\section{Ethics approval and consent to participate}

This study is part of a research project that the Ethics Committee approved of the National Center for Medical Genetics and conducted by this institution in all the municipalities and provinces of Cuba.

\section{Consent for publication}

Not applicable

\section{Availability of data and material}

The datasets used and/or analyzed during the current study are available from the corresponding author on reasonable request.

\section{Competing interests}

The authors declare that there are no competing interests.

\section{Funding}

Not applicable because this research did not receive any external funding.

\section{Authors contributions}

EMP: did conceptualization, data selection, formal analysis, methodological design, software application, visualization, was a major contributor in writing the manuscript. YZR: did research, methodological design. TCM: did research, attention to resources. ENSG and YHP: performed the molecular procedures. MAGT: did formal analysis, software application. HRB: did attention to resources, visualization. BMT: did project administration, revision and editing. All authors read and approved the final manuscript.

\section{Acknowledgements}

The authors would like to thank Miriam Ribas Hermelo for her advice and the translation of this paper.

\section{Bibliographic references}

1. Murray MF, Kenny EE, Ritchie MD, Rader DJ, Bale AE, Giovanni MA, et al. COVID-19 outcomes and the human genome. Genet Med 2020;22:1175-7. https://doi.org/10.1038/s41436-020-0832-3.

2. Pasrija R, Naime M. The deregulated immune reaction and cytokines release storm (CRS) in COVID-19 disease. Int Immunopharmacol 2021;90:107225. https://doi.org/10.1016/j.intimp.2020.107225.

3. Williams FM, Freydin M, Mangino M, Couvreur S, Visconti A, Bowyer RC, et al. Self-reported symptoms of covid-19 including symptoms most predictive of SARS-CoV-2 infection, are heritable 2020. https://doi.org/10.1101/2020.04.22.20072124.

4. Yousefzadegan S, Rezaei N. Case Report: Death due to COVID-19 in Three Brothers. Am J Trop Med Hyg 2020;102:1203-4. https:// doi.org/10.4269/ajtmh.20-0240.

5. Kenney AD, Dowdle JA, Bozzacco L, McMichael TM, St Gelais C, Panfil AR, et al. Human Genetic Determinants of Viral Diseases. Annu Rev Genet 2017;51:241-63. https://doi.org/10.1146/annurev-genet-120116-023425. 
6. Öztürk R, Taşova Y, Ayaz A. COVID-19: pathogenesis, genetic polymorphism, clinical features and laboratory findings. Turk J Med Sci. 2020 Apr 21;50(SI-1):638-57..

7. Costela-Ruiz VJ, Illescas-Montes R, Puerta-Puerta JM, Ruiz C, Melguizo-Rodríguez L. SARS-CoV-2 infection: The role of cytokines in COVID-19 disease. Cytokine Growth Factor Rev 2020;54:62-75. https://doi.org/10.1016/j.cytogfr.2020.06.001.

8. Trinchieri G. Interleukin-12: a pro-inflammatory cytokine with immunoregulatory functions that bridge innate resistance and antigen-specific adaptive immunity. Annu Rev Immunol 1995;13:25176. https://doi.org/10.1146/annurev.iy.13.040195.001343.

9. Seegers D, Zwiers A, Strober W, Peña AS, Bouma G. A Taql polymorphism in the $3^{\prime} \mathrm{UTR}$ of the IL-12 p40 gene correlates with increased IL-12 secretion. Genes Immun 2002;3:419-23. https:// doi.org/10.1038/sj.gene.6363919.

10. QIAGEN. QIAsymphony ${ }^{\circledR}$ DSP DNA Instructions for Use (Handbook) 2015.

11. World Medical Association Declaration of Helsinki: ethical principles for medical research involving human subjects. J Am Coll Dent 2014;81:14-8.

12. Garibaldi BT, Fiksel J, Muschelli J, Robinson ML, Rouhizadeh M. Perin J, et al. Patient Trajectories Among Persons Hospitalized for COVID-19 : A Cohort Study. Ann Intern Med 2021;174:33-41. https://doi.org/10.7326/M20-3905.

13. Saavedra Hernández D, García Verdecia B. Inmunosenescencia: efectos de la edad sobre el sistema inmune. Rev Cuba Hematol Inmunol Hemoter Vol 30 No 42014 Oct - DICIEMBRE 2014.

14. Plasencia-Urizarri TM, Aguilera-Rodríguez R, Almaguer Mederos LE. Comorbilidades y gravedad clínica de la COVID-19: revisión sistemática y meta-análisis. Rev Habanera Cienc Médicas Vol 19 Supl Temático COVID-19 2020
15. Pérez Rodríguez $N$ de las $M$, Remond Noa R, Torres Reyes $A$ Veranes Miranda A, Fernández Lorenzo JM, Oviedo Álvarez V. et al. Distribución de la población vulnerable a la enfermedad COVID-19 en La Habana, Cuba. Rev Cuba Hig Epidemiol Vol 57 2020 Enero - Diciembre 2020.

16. Marcheco-Teruel B, Parra EJ, Fuentes-Smith E, Salas A, Buttenschøn HN, Demontis D, et al. Cuba: exploring the history of admixture and the genetic basis of pigmentation using autosomal and uniparental markers. PLoS Genet 2014;10:e1004488. https://doi. org/10.1371/journal.pgen.1004488.

17. Oficina Nacional de Estadística e Información de la República de Cuba. El color de la piel según el censo de población y viviendas de 2012. La Habana: 2016

18. Mangalmurti N, Hunter CA. Cytokine Storms: Understanding COVID-19. Immunity 2020;53:19-25. https://doi.org/10.1016/j. immuni.2020.06.017.

19. Online Mendelian Inheritance in Man, $\mathrm{OMIM}^{\circledR}$. Johns Hopkins University, Baltimore, MD. MIM Number: 161561 2021. https://omim. org (accessed June 16, 2021).

20. Morales Peralta E, Hernández Pérez Y, Peñalver Morales K, Lamas Torres Y, Rumbaut Castillo R, Collazo Mesa T. Asociación de los polimorfismos T352C y A16974C con la lepra lepromatosa en pacientes cubanos. Rev Haban Cienc Méd 2017:16:10.

21. Sánchez de la Rosa R, Sánchez de la Rosa E, Rodríguez Hernández N. Interleucina-12 VS: Enfermedades infecciosas. Rev Cuba Med 2001;40:118-21.

22. Hashemi SMA, Thijssen M, Hosseini SY, Tabarraei A, Pourkarim MR, Sarvari J. Human gene polymorphisms and their possible impact on the clinical outcome of. Arch Virol. 2021 Aug;166(8):2089-108. 